\title{
Urotensin II Induces Mice Skeletal Muscle Atrophy Associated with Enhanced Autophagy and Inhibited Irisin Precursor (Fibronectin Type III Domain Containing 5) Expression in Chronic Renal Failure
}

\author{
Ya-Jing Pan Si-Jia Zhou Jin Feng Qiong Bai La-Ta A Ai-Hua Zhang \\ Department of Nephrology, Peking University Third Hospital, Beijing, China
}

\section{Keywords}

Urotensin II · Autophagy · Skeletal muscle cell · Irisin

\begin{abstract}
Background/Aims: Skeletal muscle atrophy is one of the main manifestations of protein energy wasting. We hypothesized that urotensin II (UII) can lead to skeletal muscle atrophy through upregulating autophagy and affecting Irisin precursor fibronectin type III domain containing 5 (FNDC5) expressions. Methods: Three animal models (the sham operation, wildtype C57BL/6 mice with 5/6 nephrectomy, UIl receptor (UT) gene knockout (UTKO) mice with $5 / 6$ nephrectomy) were designed. Skeletal muscle weight, cross-sectional area (CSA) along with UII, FNDC5, LC3, and p62 expression were investigated. C2C12 cells were differentiated for up to 4 days into myotubes. These cells were then exposed to different UIl concentrations $\left(10^{-5}\right.$ to $\left.10^{-7} \mathrm{M}\right)$ for $6-12 \mathrm{~h}$ and analyzed for the expressions of autophagic markers. These cells were also exposed to the same predetermined UII concentrations for 48-72 $\mathrm{h}$ and analyzed for the FNDC5 expression. Myotube diameter was measured. Results: Upregulation of UII expression in skeletal muscle tissue was accompanied by reduced muscle weight and skeletal muscle CSA in the 2 posterior limbs, upregulated autophagy markers expression, and downregulated FNDC5 expression in 5/6 nephrectomy mice. The decrease of skeletal muscle weight, skeletal muscle CSA, downregulation of FNDC5 expression, and the upregulation of autophagy markers were inhibited in UTKO with 5/6 nephrectomy mice. Our in vitro study showed
\end{abstract}




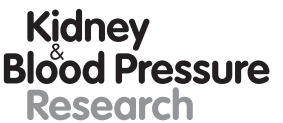

Kidney
Blood Pressure
Research

that UII could directly decrease myotube diameter, induce autophagy markers upregulation, and inhibit expression of FNDC5. When UII receptor gene was interfered by UT-specific siRNA, UII induced autophagy markers upregulation and FNDC5 downregulation were inhibited. Conclusion: We are the first to verify UII induces mice skeletal muscle atrophy associated with enhanced skeletal muscle autophagy and inhibited FNDC5 expression in chronic renal failure.

(C) 2019 The Author(s)

Published by S. Karger AG, Basel

\section{Introduction}

Protein energy wasting (PEW), the state of decreased body stores of protein and energy fuels [1], is prevalent in patients with chronic kidney disease (CKD) and increases morbidity and mortality [2]. Muscle wasting, one of the main clinical manifestations of PEW, can be caused by many risk factors associated with CKD [3-8].

The neuropeptide urotensin II (UII), originally found in the urophysis of teleost fishes [9], is the natural ligand of a human homologue $[9,10]$ of the orphan receptor GPR14 $[10,11](a$ G-protein coupled receptor, GPCR), now called the UII receptor (UTS2R, UTR, UT) [11]. Clinical studies have provided evidence that UII and UT are associated with various pathologies [12]; in addition, both UII and UT are expressed in skeletal muscle [13].

The fibronectin type III domain containing 5 (FNDC5) is processed to form a new hormone secreted into blood. This hormone is called Irisin. It has also been demonstrated that Fndc5 mRNA and Irisin synthesis are increased during myogenic differentiation of human myocytes in vitro, supporting the idea of the myogenic potential of Irisin [14].

It is verified that excessive autophagy can lead to muscle atrophy [15]. Our previous study found that circulating UII was negatively correlated with muscle mass, while serum Irisin was positively correlated with muscle mass. UII and Irisin were negatively correlated $[16,17]$. In the past, we also confirmed that upregulated UII expression is associated with enhanced autophagy in placentas of severe preeclampsia patients [18], and autophagy could cause skeletal muscle atrophy $[15,19]$. We speculate that UII can lead to skeletal muscle atrophy through affecting autophagy and FNDC5 expression. In our current study, we performed animal experiments in vivo and mouse skeletal muscle cell experiments in vitro to verify our hypothesis.

\section{Methods}

Animal Model System

The UII receptor gene knockout (UTKO) mice strain used for this research was created from ES cell clone 12922A-B6, generated by Regeneron Pharmaceuticals, Inc., and made into live mice by the KOMP Repository (www.komp.org) and the Mouse Biology Program (www. mousebiology.org) at the University of California Davis. The mice were backcrossed onto C57BL/6 mice.

Genotype Identification

According to the Mouse Biology Program, University of California Davis. Primers are

Reg-NeoF: 5'-GCAGCCTCTGTTCCACATACACTTCA-3',

Reg-UT-R: 5'-CTCTCAGATCTCTCAGCTACCTGCC-3'.

Reg-UT-wtR: 5'-CTTGAAGGAAGCTTGCTGGGATAGC-3', 


\section{Kidney \\ Blood Pressure \\ Research}

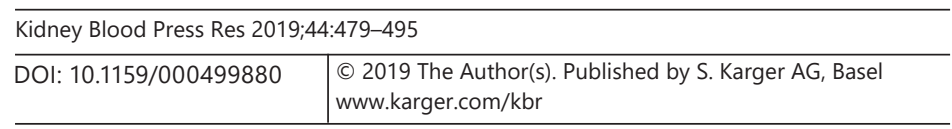

Pan et al.: UII Induces Autophagy and Inhibits FNDC5 Expression in Skeletal Muscle

Reg-UT-wtF: 5'-ATTGGGCTGCTCTATATCCGTCTGG-3'.

Genotype of Forward Primer/Reverse Primer and Amplification size(bp): Knockout Reg-NeoF/Reg-UT-R 756bp, Wild-type Reg-UT-wtF/Reg-UT-wtR 63 bp.

Toes of newborn mice within 6 weeks were cut for DNA extraction (DNA extraction kit, B40013, bimake): (1) Add $100 \mu \mathrm{L}$ protease mixture ( $2 \mu \mathrm{L}$ Protease Plus and $100 \mu \mathrm{L}$ Buffer L/ per sample) to the tissue tub. (2) Incubate at $55^{\circ} \mathrm{C}$ for $15 \mathrm{~min}$ to release genomic DNA. (3) After digestion, incubate at $95^{\circ} \mathrm{C}$ for 5 min to inactivate the proteases. (4) After centrifugation, the supernatant of digested solution can be used as the template for PCR. PCR protocol: $\mathrm{ddH}_{2} \mathrm{O} 8 \mu \mathrm{L}$, primers (10 $\mu \mathrm{M}$ each) $0.5 \mu \mathrm{L}$, template $1 \mu \mathrm{L}$, 2XM-PCR OPTI ${ }^{\mathrm{TM}}$ Mix $10 \mu \mathrm{L}$, reaction volume $21 \mu \mathrm{L}$. Cycling parameters: Temperature $94{ }^{\circ} \mathrm{C}$ for $5 \mathrm{~min} ; 94^{\circ} \mathrm{C}$ for $20 \mathrm{~s}, 55^{\circ} \mathrm{C}$ for $30 \mathrm{~s}, 72^{\circ} \mathrm{C}$ for $27 \mathrm{~s}, 35$ cycles; $72^{\circ} \mathrm{C}$ for $5 \mathrm{~min} ; 12^{\circ} \mathrm{C}$ finished.

Amplification at 756 bp meant that UII receptor was knocked out and amplification at 63 bp meant wild type. When both 756 and 63 bp band show up on the gel, this indicates heterozygous genotype, while a single $756 \mathrm{bp}$ band indicates homozygous genotype (KO mice; online suppl. Fig. S1; for all online suppl. material, see www.karger.com/doi/10.1159/000499880).

Wild-type C57BL/6 mice were purchased from Vital River Laboratory Animal Technology (Beijing, China). Three animal models (the sham operation mice as normal control [NC] group, wild-type C57BL/6 mice with 5/6 nephrectomy as wild-type chronic renal failure [WT CRF] group, UTKO C57BL/6 mice combined with 5/6 nephrectomy as UTKO chronic renal failure group [UTKO CRF]) were designed. Experiments were performed on 10 UTKO male mice and 20 wild-type male mice at 4-6 weeks of age. The mice weighed between 20 and $25 \mathrm{~g}$. The mice were housed under standard condition (temperature $23 \pm 2^{\circ} \mathrm{C}$, humidity of $50 \%$, and a $12 \mathrm{~h}$ on/ off cycle for lighting). The mice were divided into 3 groups: 10 knockout mice with 5/6 nephrectomy, 10 wild-type mice with 5/6 nephrectomy [20], and 10 wild-type mice that received sham-operated surgery. The group of wild-type mice that received sham surgery was designated as the NC group. All mice were sacrificed 18 weeks after the surgery, which was the needed time period for the mice with 5/6 nephrectomy to develop advanced stage renal failure. Nine mice from the sham group survived, 6 mice from the wild-type mice with 5/6 nephrectomy group survived and 7 mice from the UTKO mice with 5/6 nephrectomy group survived.

\section{Plasma UII Measurement Using Radioimmunoassay}

Reconstitute standard peptide, positive control, and samples with RIA buffer into duplicate tubes. Pipette $100 \mu \mathrm{L}$ of antibody into all tubes, vortex and then incubate all tubes at $4{ }^{\circ} \mathrm{C}$ for $16-24 \mathrm{~h}$. Add $100 \mu \mathrm{L}$ of ${ }^{125}$ I-peptide working tracer solution to each tube, vortex and incubate all tubes for another $16-24 \mathrm{~h}$ at $4^{\circ} \mathrm{C}$. Add $100 \mu \mathrm{L}$ of goat antirabbit serum, normal rabbit serum to each tube, vortex, and incubate at room temperature for at least 90 min. Add $500 \mu \mathrm{L}$ of RIA buffer to each tube, vortex, centrifuge, and aspirate all the supernatant. Use a $\gamma$-counter to count the cpm of the pellet (The kit was bought from Phoenix Pharmacenticals, Inc. RK-071-08.)

\section{Cell Culture and Differentiation}

C2C12 murine skeletal muscle myoblasts were bought from National Infrastructure of Cell Line Resource (Beijing, China). C2C12 cells were grown in Dulbecco's modified Eagle's medium (DMEM)/HIGH GLUCOSE (HyClone, Logan, USA) supplemented with 10\% (v/v) fetal bovine serum (BI), $50 \mathrm{U} / \mathrm{mL}$ penicillin, and $50 \mu \mathrm{g} / \mathrm{mL}$ streptomycin (HyClone) in a humidified incubator containing $5 \% \mathrm{CO}_{2}$ at $37^{\circ} \mathrm{C}$. When cell density reached more than $80 \%$, cells were differentiated into myotubes by $2 \%(\mathrm{v} / \mathrm{v})$ horse serum (HyClone) DMEM/HIGH GLUCOSE containing $50 \mathrm{U} / \mathrm{mL}$ penicillin and $50 \mu \mathrm{g} / \mathrm{mL}$ streptomycin for up to 4 days. Myotubes were then exposed to different concentrations of UII, ranging from $10^{-5}$ to $10^{-7} \mathrm{M}$ (U7257, Sigma, USA) for $6,12,48$, and $72 \mathrm{~h}$. 


\section{Kidney \\ Blood Pressure \\ Research}

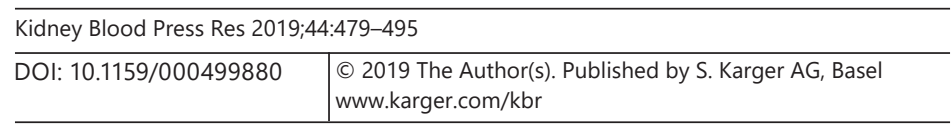

Pan et al.: UII Induces Autophagy and Inhibits FNDC5 Expression in Skeletal Muscle

\section{Image Capture and Cell Size}

Images from differentiated myotubes exposed to $10^{-5}$ to $10^{-7} \mathrm{M}$ of UII for $48 \mathrm{~h}, 10^{-7} \mathrm{M}$ of UII for $6,12,48,72 \mathrm{~h}$ were visualized at 20 magnifications using an inverted light microscope (Nikon) and captured with software NIS-Elements F 4.30.00. Myotube diameter was measured from randomly selected microscope fields from 3 different wells of control and treated conditions. At least 3 diameters were measured per myotube, and at least 20 myotubes were measured per well using Image Pro Plus software [21].

\section{The Transfection of UT siRNA to C2C12 Cells}

UT siRNA was purchased from Gene Pharma (Suzhou, China), and GAPDH siRNA was bought from Sangon (Shanghai, China). The transfection of UT siRNA to C2C12 cells was performed in 6-well plates with Lipofectamine RNAiMAX (Invitrogen Corp.) according to the manufacturer's instructions with minor modification. Transfection was conducted on day 3 of the differentiation in C2C12 cells. After 24-h transfection, transfection medium was replaced by differentiation medium containing $10^{-7} \mathrm{M}$ UII in each well except for the NC group. Then, myotubes were harvested for Western blot analysis. For UT siRNA transfection effect examination result, please see online suppl. Figure S3.

The siRNA oligonucleotides designed were shown as below,

UT-siRNA-1 targeting sequence 5'-GCUGUAUCUGCUGAGCAUUTA-3',

UT-siRNA-2 targeting sequence $5^{\prime}$-GGACUUCCUGACAAUGCAUTT-3',

UT-siRNA-3 targeting sequence $5^{\prime}$-GCUCCAAGGGUUACCGUAATT-3',

Nontargeting control siRNA 5'-UUCUCCGAACGUGUCACGUTT-3',

GAPDH siRNA targeting sequence 5'-UGACCUCAACUACAUGGUUTT-3'.

\section{Cross-Sectional Area of Muscle Fibers}

The measurement of cross-sectional area (CSA) was performed according to the methods of published study with minor modification [22]. The CSA of hematoxylin and eosin stained muscle (fibers number, $n=30$ ) in 5 fields from each animal were randomly chosen and determined using the Image J program. CSA of each group was then calculated. The total fiber number was calculated using an image of $200 \times$ magnification from the entire field of muscle section, which was randomly chosen.

\section{Immunohistochemical Analysis}

Immunohistochemical analysis was performed on gastrocnemius muscle tissues. The thickness of $5 \mu \mathrm{m}$ sections were made from the paraffin's embedded muscles. Then $3 \%$ hydrogen peroxide was incubated in order to delete endogenous peroxidase. The sections were performed with primary antibodies at $4{ }^{\circ} \mathrm{C}$ overnight, and PBS served as a substitute for the primary antibody in negative control group. The tissue slices were then incubated with second antibody for $30 \mathrm{~min}$.

3,3'-Diaminobenzidine staining was used to distinguish positive antigen from negative antigen. Brown deposits indicated positive staining. Then, $200 \times$ high-power microscope fields were randomly selected to calculate the integral optical density of positive staining. The antibodies to UII (ab194676), FNDC5 (ab181884), LC3 (ab48394), and p62 (ab56416) were bought from Abcam (Cambridge, UK).

\section{Western Blot Analysis}

Gastrocnemius muscle protein was extracted and mixed with $5 \times$ loading buffer (Applygen, Beijing, China). The protein was then denatured at $100^{\circ} \mathrm{C}$ for $5 \mathrm{~min}$ and then loaded on a SDS-PAGE gel prior to being transferred to NC membranes. Following the immersion of membranes with 5\% BSA (AMRESCO Inc., OH, USA), membranes were incubated with primary rabbit polyclonal anti-UII antibody (ab194676, Abcam), primary rabbit polyclonal anti-LC3 
Table 1. Comparison of basic parameters among NC group, WT CRF group, and UTKO CRF group

\begin{tabular}{lccc}
\hline Variables & NC group $(n=9)$ & WT CRF group $(n=6)$ & UTKO CRF group $(n=7)$ \\
\hline Body weight, g & & & \\
$\quad$ Preoperation & $21.83 \pm 0.85$ & $21.80 \pm 0.95$ & $22.07 \pm 0.70$ \\
$\quad$ Postoperation & $33.43 \pm 1.95$ & $31.60 \pm 3.87$ & $27.27 \pm 1.21^{\# \&}$ \\
Plasma Glu, mmol/L & & & $8.09 \pm 1.98$ \\
$\quad$ Preoperation & $8.53 \pm 1.81$ & $8.12 \pm 1.31$ & $9.56 \pm 2.32$ \\
$\quad$ Postoperation & $7.87 \pm 0.45$ & $8.36 \pm 1.04$ & $111.40 \pm 3.91$ \\
SBP, mm Hg & & & $111.17 \pm 4.36$ \\
$\quad$ Preoperation & $112.67 \pm 5.09$ & $110.33 \pm 6.86$ & $70.80 \pm 9.89$ \\
$\quad$ Postoperation & $109.60 \pm 2.61$ & $110.50 \pm 5.75$ & $70.00 \pm 2.53$ \\
DBP, mm Hg & & & $81.07 \pm 6.70$ \\
$\quad$ Preoperation & $70.33 \pm 2.80$ & $70.50 \pm 1.87$ & $93.08 \pm 8.67^{\#}$ \\
$\quad$ Postoperation & $69.40 \pm 4.62$ & $71.33 \pm 2.07$ & \\
Plasma UII, pg/mL & & & \\
$\quad$ Preoperation & $81.83 \pm 5.85$ & $92.80 \pm 4.95$ & \\
$\quad$ Postoperation & $80.92 \pm 4.48$ & & \\
\hline
\end{tabular}

$* p<0.05$ compared with normal control.

${ }^{\#} p<0.05$ compared with normal control.

$\& p<0.05$ compared with WT CRF group.

$p$ values below 0.05 have been accepted to be significant.

NC, normal control; WT, wild type; UTKO, Urotensin II receptor gene knock out; CRF, chronic renal failure; Alb, albumin; Glu, glucose; SBP, systolic blood pressure; DBP, diastolic blood pressure; UII, Urotensin II.

Fig. 1. Comparison of plasma BUN changes among 3 experimental animal models. NC: Sham operation as NC. WT CRF: Wildtype mice with 5/6 nephrectomy. UTKO CRF: UTKO with 5/6 nephrectomy mice. WT CRF vs. NC, ${ }^{*} p<0.05$; UTKO CRF vs. NC, ${ }^{\#} p<$ 0.05 . BUN, blood urea nitrogen; NC, normal control; WT CRF, wild-type chronic renal failure; UTKO CRF, UII receptor gene knockout chronic renal failure group.

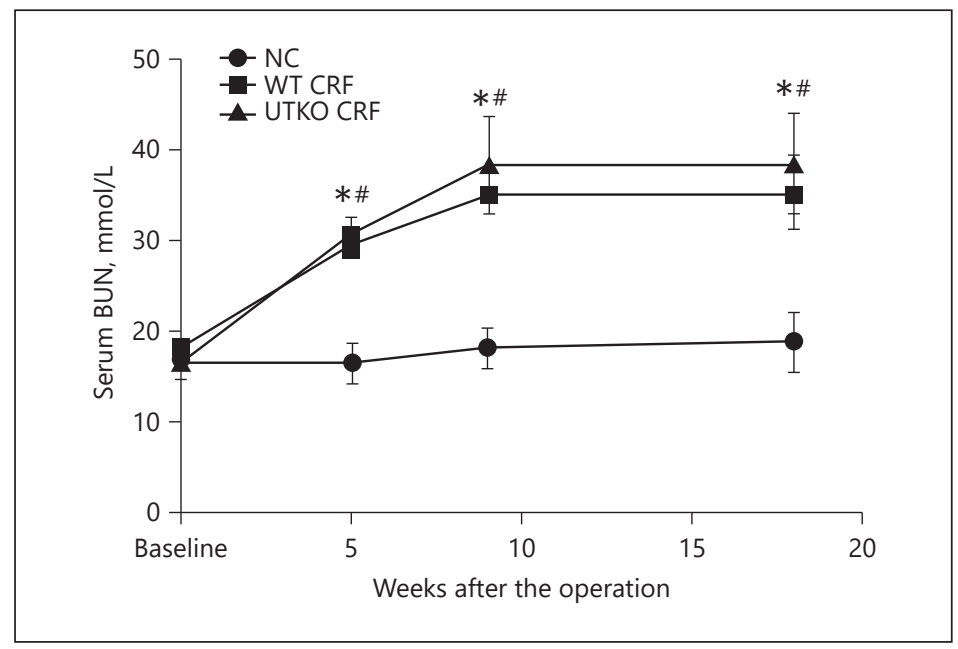

antibody (ab48394, Abcam), primary mouse monoclonal anti-p62 antibody (ab56416, Abcam), and primary rabbit polyclonal anti-FNDC5 antibody (ab131390, Abcam) overnight at $4{ }^{\circ} \mathrm{C}$. Membranes were then incubated with fluorescence-conjugated antirabbit and antimouse antibodies (LI-COR, NE, USA). Semi-quantitative gray-scale intensity was measured by image J. The antibody of GAPDH was purchased from Byeotime (Shanghai, China).

\section{Statistical Analysis}

All values were expressed as means $\pm \mathrm{SE}$. Statistical significance was analyzed by one-way ANOVA followed by post hoc comparison with SLD test (variance similar) or Dunnett's T3 
Kidney

Blood Pressure Research

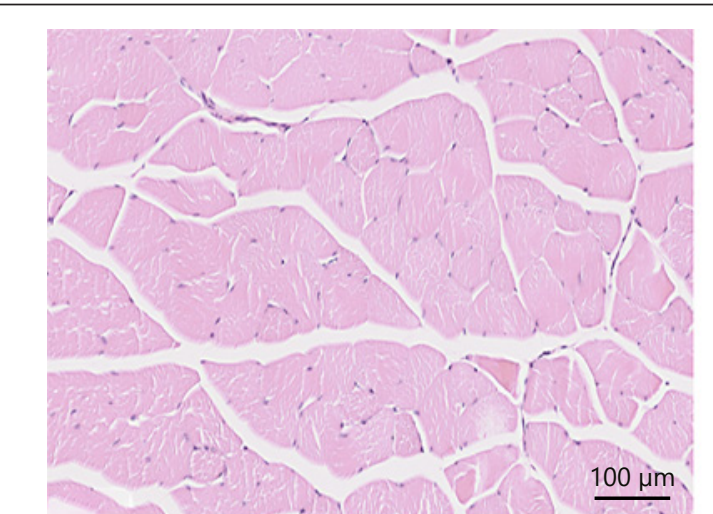

a

$\mathrm{NC}$

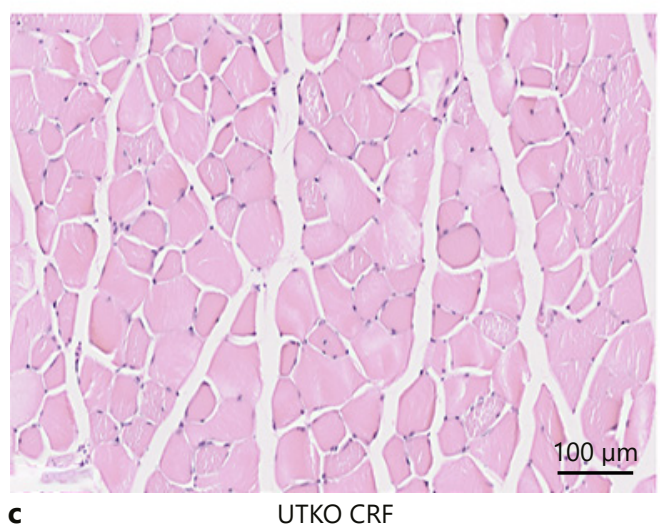

2019 The Author(s). Published by S. Karger AG, Basel www.karger.com/kbr

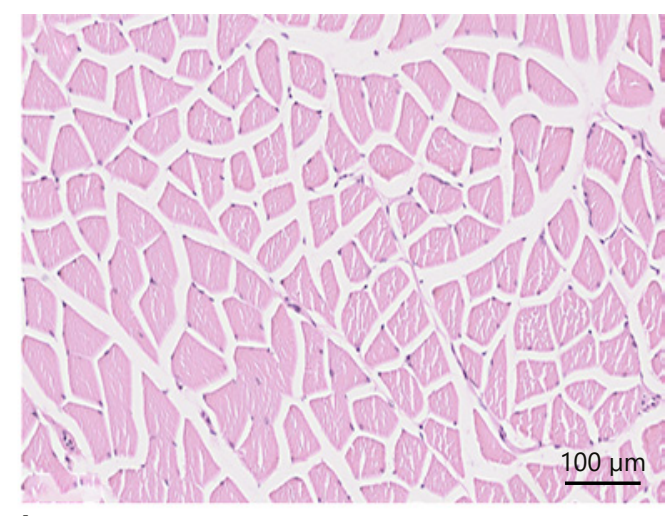

b

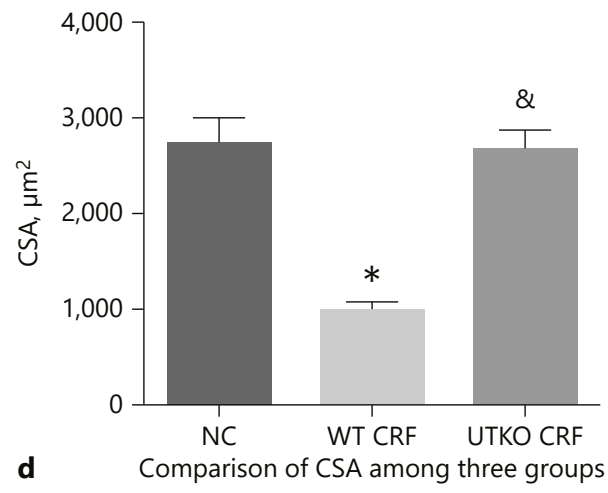

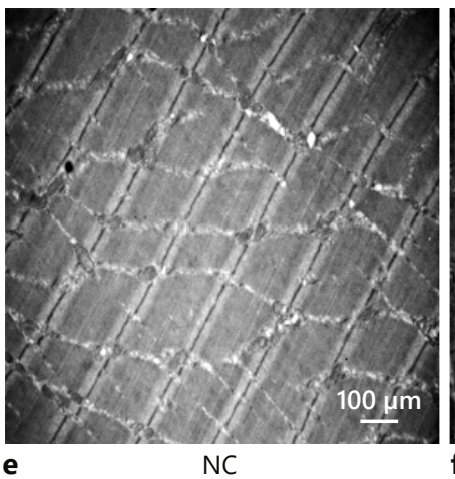
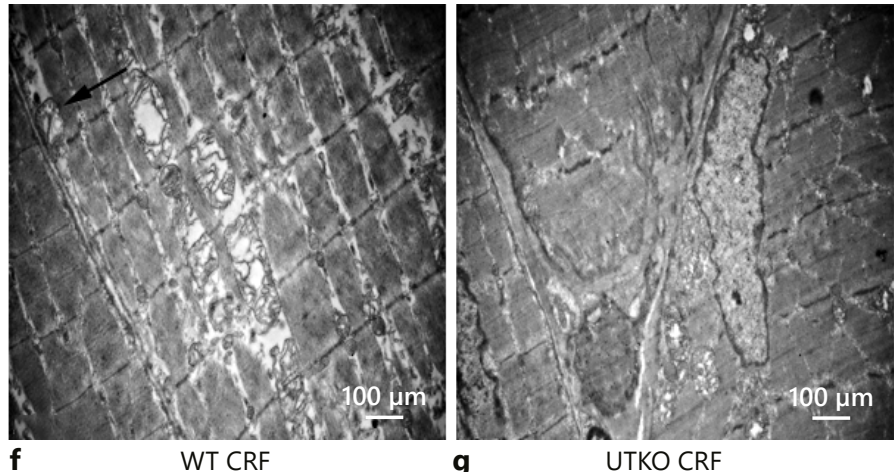

Fig. 2. Comparisons of muscle CSA and skeletal muscle ultrastructure among 3 groups by HE stain and electronic microscope examination. a NC: Sham operation as NC. b WT CRF: Wild-type mice with 5/6 nephrectomy. c UTKO CRF: UTKO with 5/6 nephrectomy mice. d Comparison of CSA among 3 groups. * $p<0.05$ vs. NC, \& $p<0.05$ vs. WT CRF. CSA: cross sectional area. Scale bar $=100 \mu \mathrm{m}$ in (a-c). e NC by electronic microscope examination (EM). $\mathbf{f}$ WT CRF by EM. $\mathbf{g}$ UTKO CRF by EM. Arrows indicate autophagosomes in (f). Scale bar $=1 \mu \mathrm{m}$ in (e-g). CSA, cross sectional area; NC, normal control; WT CRF, wild-type chronic renal failure; UTKO CRF, UII receptor gene knockout chronic renal failure group.

(variance without similar) (Fig. 1, 2a-c, 3, 4, 7e,f, 8b, c; Table 1), Dunnett's multiple comparison test (Fig. 5, 6, 7a-d; online suppl. Fig. S2, S3c), and independent-samples $t$ test (online suppl. Fig. S3b; Fig. 8a). The differences among groups were considered statistically significant at $p<0.05$. All the statistical analyses were performed with SPSS 20.0 for Windows (SPSS Inc., Chicago, IL, USA). 


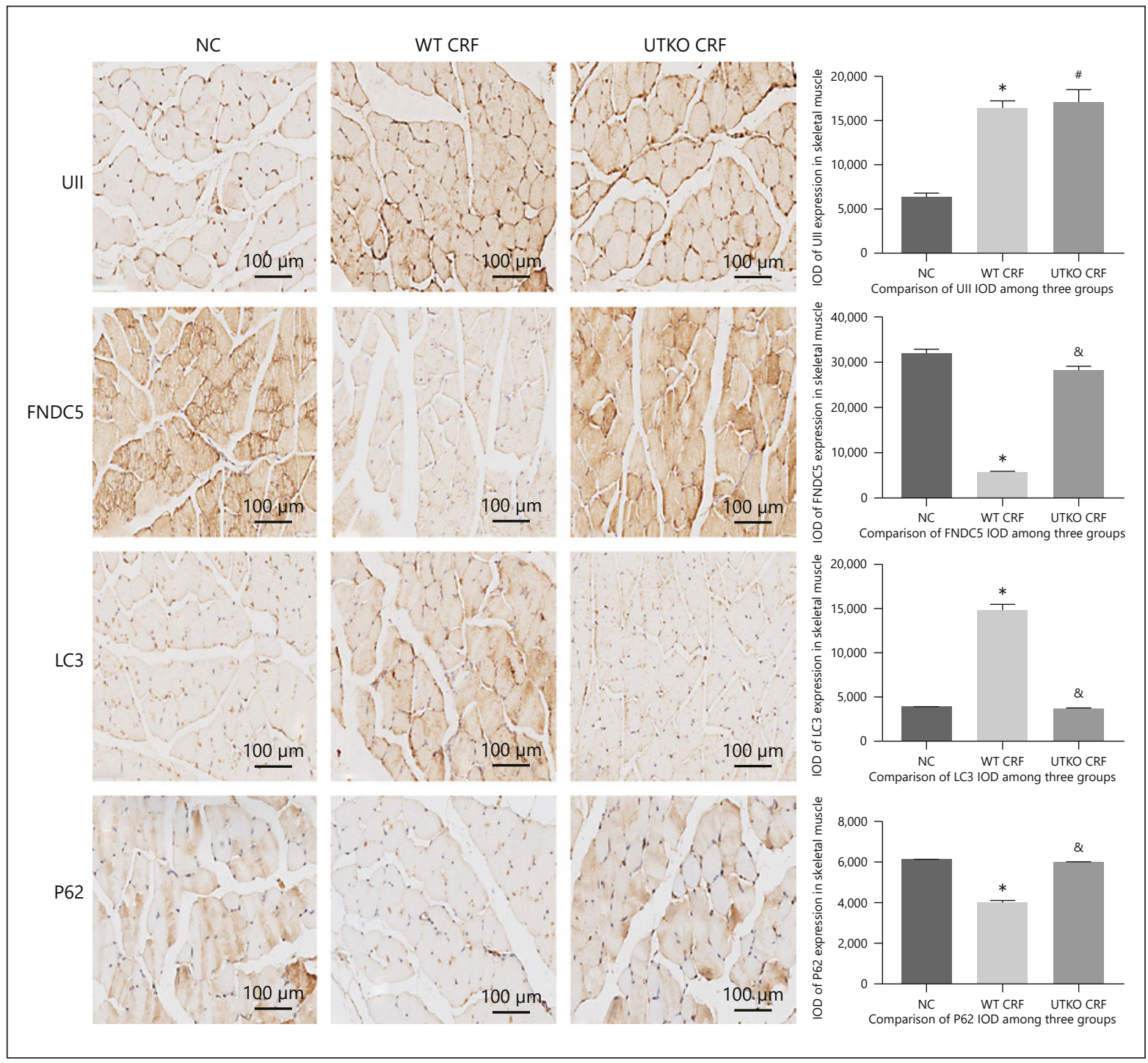

Fig. 3. Expression of UII, FNDC5, LC3 and p62 in 3 groups detected by immunochemistry. NC: sham operation as NC. WT CRF: wild-type mice with 5/6 nephrectomy. UTKO CRF: UTKO with 5/6 nephrectomy mice ( ${ }^{*} p<0.05$ vs. NC, ${ }^{*} p<0.05$ vs. NC, ${ }^{\&} p<0.05$ vs. WT CRF). Scale bar $=100 \mu \mathrm{m}$. FNDC5, fibronectin type III domain containing 5; IOD, integral optical density; UII, urotensin II; NC, normal control; WT CRF, wild-type chronic renal failure; UTKO CRF, UII receptor gene knockout chronic renal failure group.

\section{Results}

\section{Animal Experiments Results}

Changes of Renal Function and Other Parameters among Three Animal Model Groups

There were no differences among 3 groups (NC, WT CRF, and UTKO CRF) in serum blood urea nitrogen (BUN) levels before operation (baseline level). Serum BUN levels were significantly increased both in WT CRF and UTKO CRF mice at 5, 9, and 18 weeks after the operation in comparison to the sham operation NC. However, there were no significant differences in serum BUN levels between WT CRF group and UTKO CRF group (Fig. 1). There were no differences in serum glucose, systolic blood pressure, and diastolic blood pressure among 3 groups both preoperation and postoperation. Different degrees of body weight increases were 


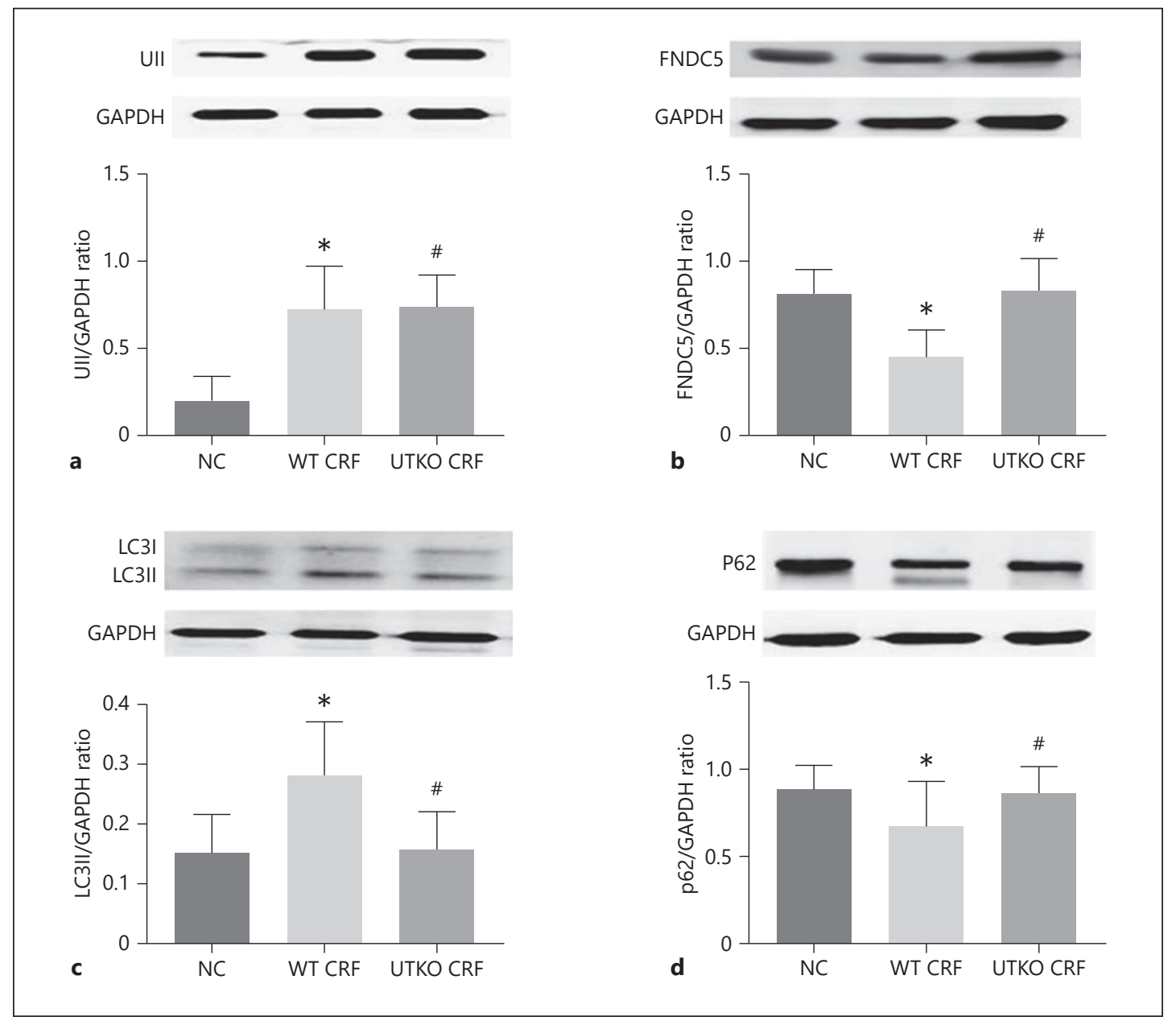

Fig. 4. Comparison of UII, FNDC5, LC3II and p62 expression among 3 groups by western blot. NC: sham operation as NC. WT CRF: wild-type mice with 5/6 nephrectomy. UTKO CRF: UTKO with 5/6 nephrectomy mice. ${ }^{*} p<0.05$ vs. NC, ${ }^{\#} p<0.05$ vs. NC, ${ }^{\&} p<0.05$ vs. WT CRF. FNDC5, fibronectin type III domain containing 5; UII, urotensin II; NC, normal control; WT CRF, wild-type chronic renal failure; UTKO CRF, UII receptor gene knockout chronic renal failure group.

observed among the 3 groups 18 weeks after the operation, and the weight of UTKO CRF mice was significantly lower than that of the NC and WT CRF mice (Table 1).

We demonstrated plasma UII concentration in our mouse models was increased in WT CRF and in UTKO CRF group 18 weeks after operation compared to that of the NC mice while there was no significant difference in plasma UII concentration between WT CRF and UTKO CRF groups (Table 1).

Comparison of Muscle Wet Weight and CSA of Skeletal Muscle and Electronic Microscope Examination among Three Animal Model Groups

Our study found that WT CRF mice had a lighter mean muscle wet weight of 2 posterior limbs in comparison to that of the NC group ( $0.151 \pm 0.012$ vs. $\left.0.193 \pm 0.020 \mathrm{~g},{ }^{*} p=0.015\right)$, while UTKO CRF mice had a significant increase in mean muscle wet weight of 2 posterior limbs compared to that of the WT CRF mice $\left(0.184 \pm 0.012\right.$ vs. $0.151 \pm 0.012 \mathrm{~g}$, $\left.{ }^{\&} p=0.039\right)$. In addition, CSA in WTCRF group was smaller than the CSA in NC group $(1,040.61 \pm 58.36$ vs. 2,730.97 \pm $\left.243.57 \mu \mathrm{m}^{2},{ }^{*} p<0.05\right)$, whereas UTKOCRF mice had larger CSA compared to that of WTCRF mice 


\section{Kidney \\ Blood Pressure \\ Research}

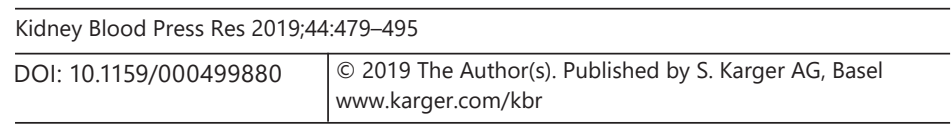

Pan et al.: UII Induces Autophagy and Inhibits FNDC5 Expression in Skeletal Muscle

$\left(2,667.30 \pm 20,290.73\right.$ vs. $\left.1,040.61 \pm 58.36 \mu \mathrm{m}^{2}, \& p<0.05\right)$ (Fig. 2a-d). Our results verified that skeletal muscle atrophy in chronic renal failure mice could be alleviated by blocking UT.

We observed intact Z-lines and mitochondria distributed in pairs around the Z line in NC group (Fig. 2e). However, mitochondria were swollen and muscle fibers were destroyed in WT CRF group. In addition, we found increased autophagosome formation (Fig. $2 \mathrm{f}$ as indicated by the arrows). On the other hand, the swollen mitochondria and destroyed muscle fibers were less apparent in UTKO CRF group (Fig. 2g).

Expression of UII, FNDC5, and Markers of Autophagy in the Skeletal Muscle Tissues of

Three Groups as Detected by Immunochemistry

Our immunochemistry study verified that there are expressions of UII, FNDC5, LC3, and p62 in the cytoplasm and membrane of skeletal muscle cells (Fig. 3). UII integrated optical density was higher in the WT CRF group and UTKO CRF group than that of the NC group. However, FNDC5 expression was lower in the WTCRF group than that of the NC group, but FNDC5 expression was significantly higher in UTKO CRF group compared to that of the WT CRF group. Moreover, LC3 expression was higher in the WTCRF group than that of the NC group. At the same time, LC3 expression was significantly decreased in UTKO CRF group compared to that of the WT CRF group. Expression of p62 was lower in the WT CRF group than that of the NC group, while p62 expression was significantly higher in UTKO CRF group compared to that of the WT CRF group.

Expression of UII, FNDC5, and Markers of Autophagy in Skeletal Muscle Tissues of

Three Groups as Detected by Western Blot

Western blot analysis showed that there were differences in expressions of UII, FNDC5, LC3, and p62 among 3 groups. Compared to that of the NC group, WT CRF mice and UTKO CRF mice had a higher expression of UII in skeletal tissues (Fig. 4a), which meant that UTKO did not affect the expression of UII. WT CRF mice had a lower expression of FNDC5 in comparison to that of the NC group, but UTKO CRF mice had higher expression of FNDC5 in comparison to that of WT CRF mice (Fig. 4b). Moreover, we found that LC3II expression in WT CRF mice was significantly higher than that of the NC group, and LC3II expression upregulation was inhibited in UTKO CRF group compared to that of the WT CRF (Fig. 4c). While p62 expression was significantly lower in WT CRF group, p62 expression was upregulated in UTKO CRF group compared to that of the WT CRF (Fig. 4d).

According to our immunochemistry and western blot results, we demonstrated that UII expression upregulation in skeletal tissues was accompanied by upregulation of autophagy markers and inhibition of FNDC5 expression in chronic renal failure mice (WTCRF mice). However, UTKO (CRF mice) could inhibit autophagic levels and alleviate the inhibited FNDC5 expression.

\section{Cell Experiment}

UII Induces Mice Myotube Atrophy

The analysis of myotube diameter showed that when myotubes are exposed to UII for 6 or $12 \mathrm{~h}$, myotubes did not display significant changes in diameter compared to that of the NC group. However, when the exposure time was extended to 48 and $72 \mathrm{~h}$, it is observed that the diameter of the UII exposed group was significantly smaller compared to that of the NC group (Fig. 5a-f). Myotubes exposed to $10^{-7} \mathrm{M}$ UII had significantly smaller diameter compared to that of the NC group exposed for 48 and $72 \mathrm{~h}$. However, there were no significant differences among NC, $10^{-5} \mathrm{M}$ UII, and $10^{-6} \mathrm{M}$ UII group (Fig. 6a-e), Moreover, we did not observe the concentration-dependent effects of UII on myotube diameter when cells were incubated in medium containing $10^{-5}$ to $10^{-7}$ M UII for $6,12,24,48$, and $72 \mathrm{~h}$ (online suppl. Fig. S2). 


\section{Kidney \\ Blood Pressure \\ Research}

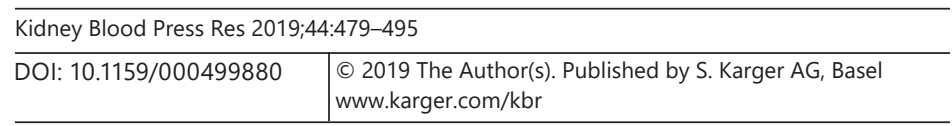

Pan et al.: UII Induces Autophagy and Inhibits FNDC5 Expression in Skeletal Muscle

UII Induces Autophagy of C2C12 Cells

In order to interfere with the effect of UII in C2C12 cells, we design UT-specific siRNAs. Myotubes transfected with GAPDH-specific siRNA were seen as the positive control, and nontarget siRNA seen as the negative control. We observed the downregulated expression of GAPDH compared to that of the nontarget siRNA group ( ${ }^{* *} p<0.01$; online suppl. Fig. S3b). UT expression was significantly downregulated in myotubes transfected with UT-specific siRNA compared to that of the myotubes transfected with nontarget siRNA ${ }^{* *} p<0.01$; online suppl. Fig. S3c). Then, we chose UT siRNA-3 for our subsequent studies.

Western blot assay indicated that myotubes exposed to UII $\left(10^{-5}\right.$ to $\left.10^{-7} \mathrm{M}\right)$ showed a higher expression of LC3II; however, significantly lower expression of p62 was only observed when myotubes were exposed under $10^{-7} \mathrm{M}$ UII for $6 \mathrm{~h}$, which showed that autophagy flux was unobstructed (Fig. 7a, b). UII exposure for $12 \mathrm{~h}$ did not significantly downregulate p62 but upregulate LC3II, which meant autophagy flux was obstructed (Fig. 7c, d).

We also found LC3II expression upregulation induced by UII was attenuated in myotubes transfected with UT-specific siRNA (Fig. 7e). Consistent with this finding, p62 expression was upregulated in myotubes transfected with UT-specific siRNA when compared to that of the UII exposure group (Fig. 7f).

\section{UII Could Downregulates the Expression of FNDC5}

UII inhibits expression of FNDC5 in myotubes when myotubes was exposed to $10^{-7} \mathrm{M}$ UII for 48 and 72 h (Fig. 8a). However, when UII was interfered (UT siRNA transfected), the downregulation of FNDC5 expression induced by UII exposure was attenuated both in the 48 and $72 \mathrm{~h}$ group in comparison to that of the UII exposure alone ( ${ }^{\&} p=0.006$ vs. UII exposure alone for 48 h in Fig. 8b; ${ }^{\&} p=0.004$ vs. UII exposure alone for 72 h in Fig. 8c).

\section{Discussion}

Skeletal muscle wasting and atrophy are characteristics of PEW in CKD [23]. Muscle wasting in CKD patients can be attributed to 2 factors: excessive protein degradation and reduced protein synthesis. It is reported that leptin, proinflammatory cytokines, myostatin, angiotensin II [24], and parathyroid hormone [25], and so on, play important roles in skeletal muscle atrophy in CKD condition.

In our study, we verified that UII-induced skeletal muscles atrophy in a time-dependent manner. However, this maximum effect of UII concentration on myotube atrophy was already present when exposed to a concentration of $10^{-7} \mathrm{M}$ but not at the concentration of $10^{-5} \mathrm{M}$, indicating that the triggering of skeletal muscle atrophy with UII is not dose-dependent (from 6 to $72 \mathrm{~h}$ ). In our in vivo study, we found that serum BUN and muscle UII expression were significantly increased in the WT CRF group. Plasma UII concentration was also increased, while skeletal muscle weight and CSA were significantly decreased in comparison to that of the NC. When we interfered with UII action by knocking out UT gene (UTKO CRF mice), skeletal muscle atrophy was attenuated in chronic renal failure mice.

Upregulation of skeletal muscle autophagy was verified under various conditions and disease states $[6,26,27]$. Autophagy was found to play a crucial role in muscle atrophy [15, 19].

We are the first to demonstrate that UII exposure can directly induce skeletal cell autophagy marker (LC3II) upregulation in myotubes (differentiated from C2C12 cells) and the most optimal UII concentration inhibiting autophagy was $10^{-7} \mathrm{M}$ but not $10^{-5} \mathrm{M}$. This meant that UII-induced myotubes autophagy was not dose-dependent. Moreover, under $10^{-7} \mathrm{M}$ UII exposure for $6 \mathrm{~h}$, we demonstrated a significant lower expression of p62, which 


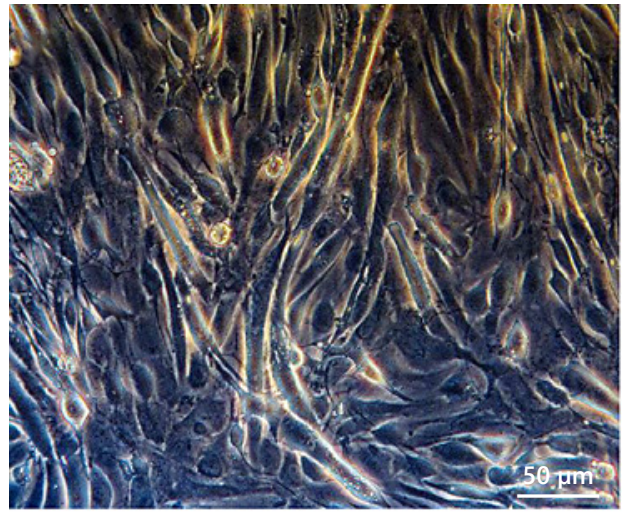

a

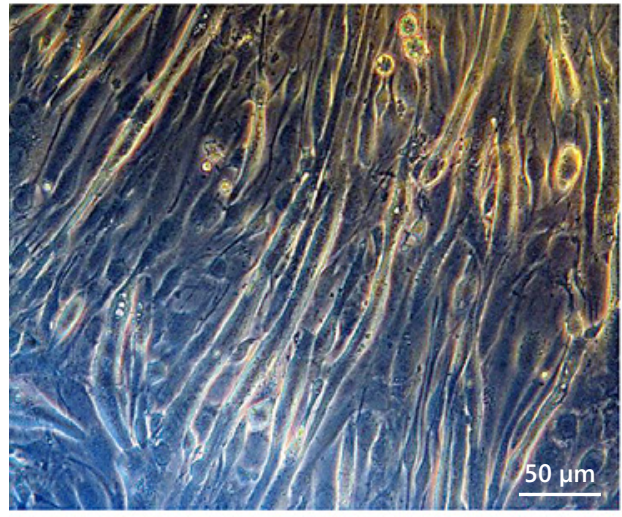

c

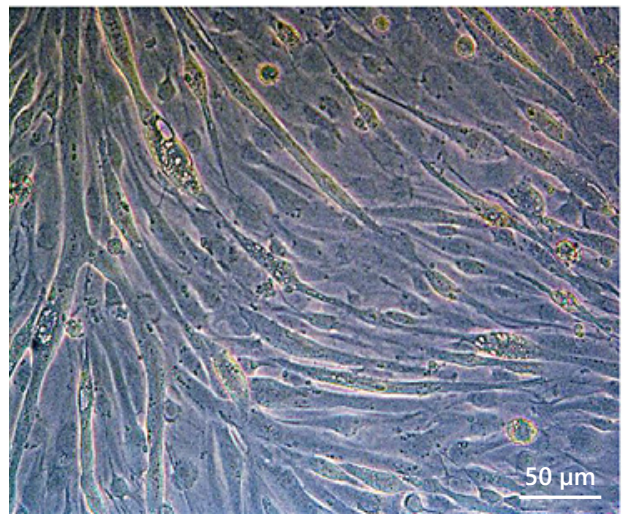

e
$\mathrm{UII}-12 \mathrm{~h}$

NC-6 h

UII-72 h

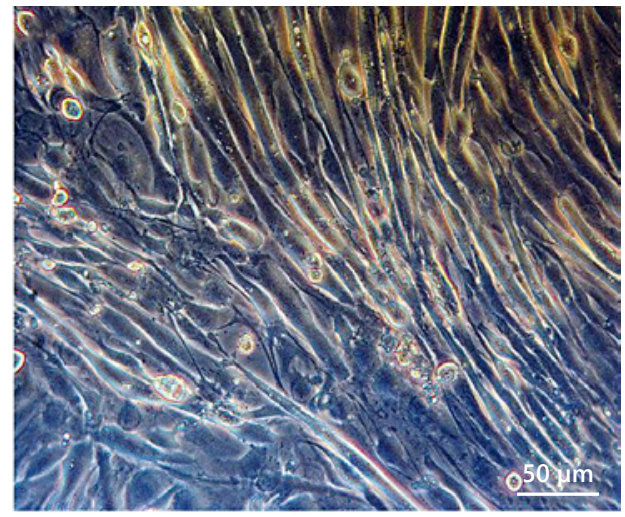

UII-6 h

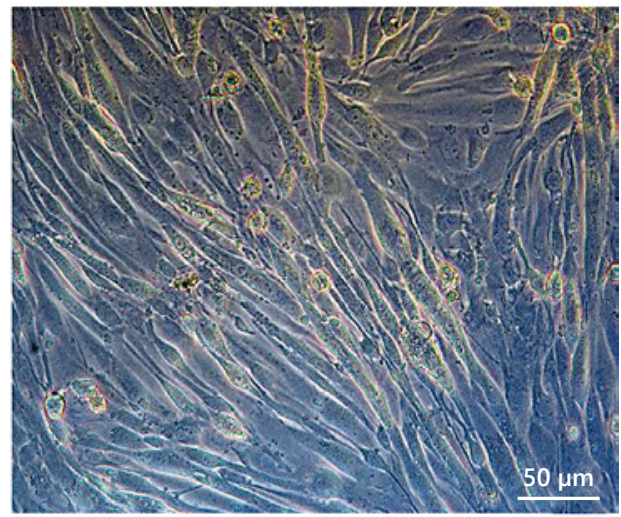

UII-48 h

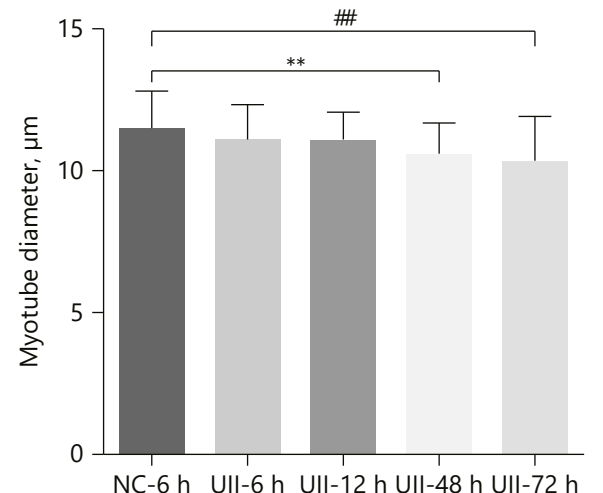

f Comparison of myotube diameter in different UII exposure time

Fig. 5. The effect of UII with different exposed time on mouse myotube diameters. a NC: PBS serving as a substitution for UII. b-e $10^{-7}$ M UII exposure time $6,12,48,72 \mathrm{~h}$ respectively. $\mathbf{f}$ Comparison of myotube diameter in different UII exposure time ( ${ }^{* *} p=0.005$ vs. NC, \#\# $p=0.001$ vs. NC). Scale bar $=50 \mu \mathrm{m}$. UII, urotensin II; NC, normal control.

indicated that autophagy flux was unobstructed. In contrast, UII exposure for $12 \mathrm{~h}$ did not down-regulate p62 but upregulate LC3II, which meant autophagy flux was obstructed, and these phenomena hinted that UII exposure on autophagy was not time dependent. Then, we interfered with UII action by transfecting UT gene-specific siRNA, and we found that autophagy 
Kidney

Blood Pressure

Research

\begin{tabular}{l|l}
\hline Kidney Blood Press Res 2019;44:479-495 \\
\hline DOI: 10.1159/000499880 & $\begin{array}{l}\text { @ 2019 The Author(s). Published by S. Karger AG, Basel } \\
\text { www.karger.com/kbr }\end{array}$ \\
\hline
\end{tabular}

Pan et al.: UII Induces Autophagy and Inhibits FNDC5 Expression in Skeletal Muscle

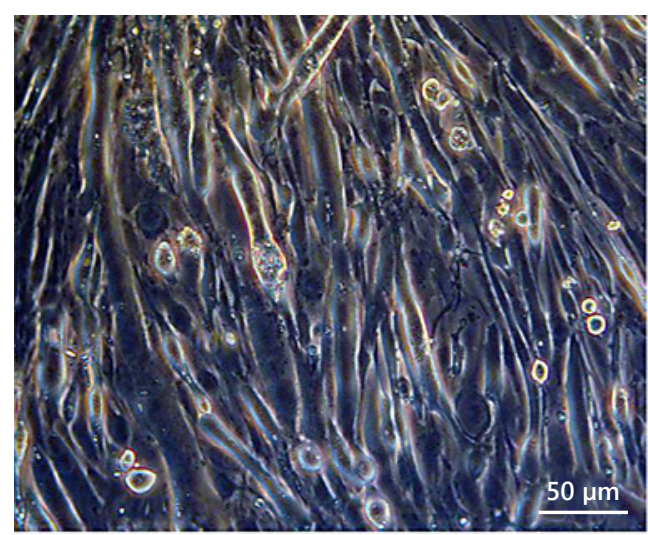

a

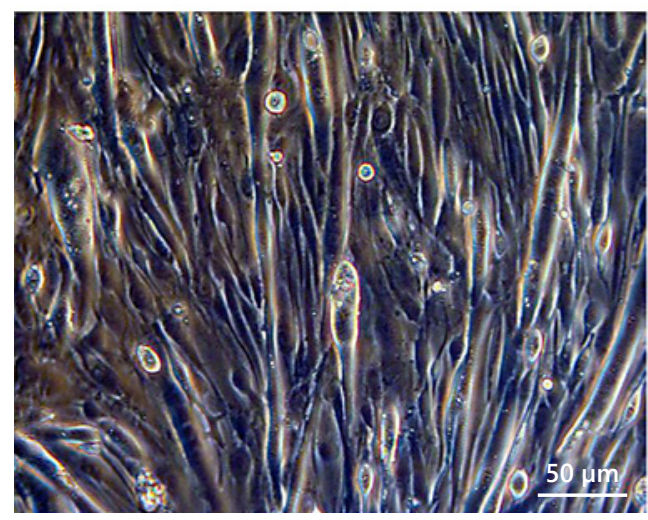

C
UII $10^{-6} \mathrm{M}$

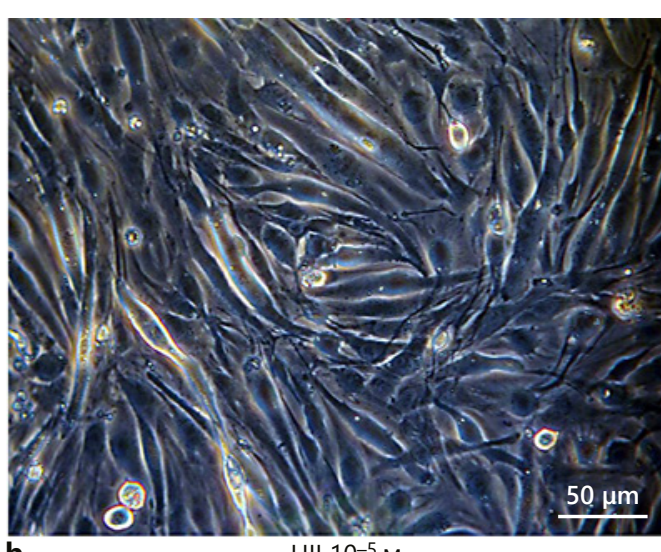

UII $10^{-5} \mathrm{M}$

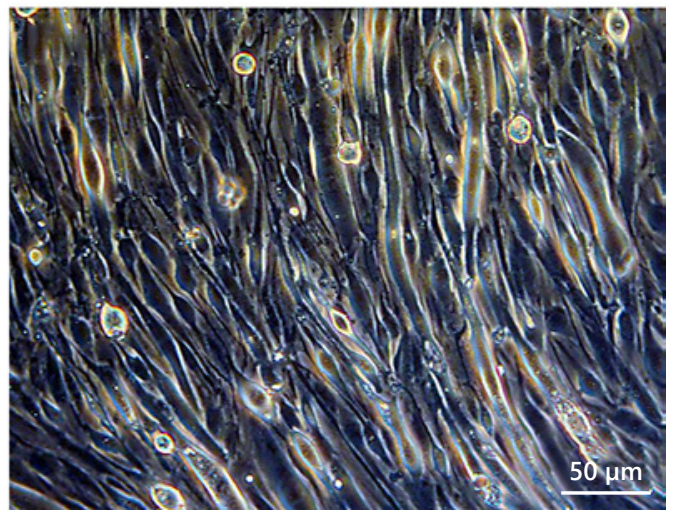

d

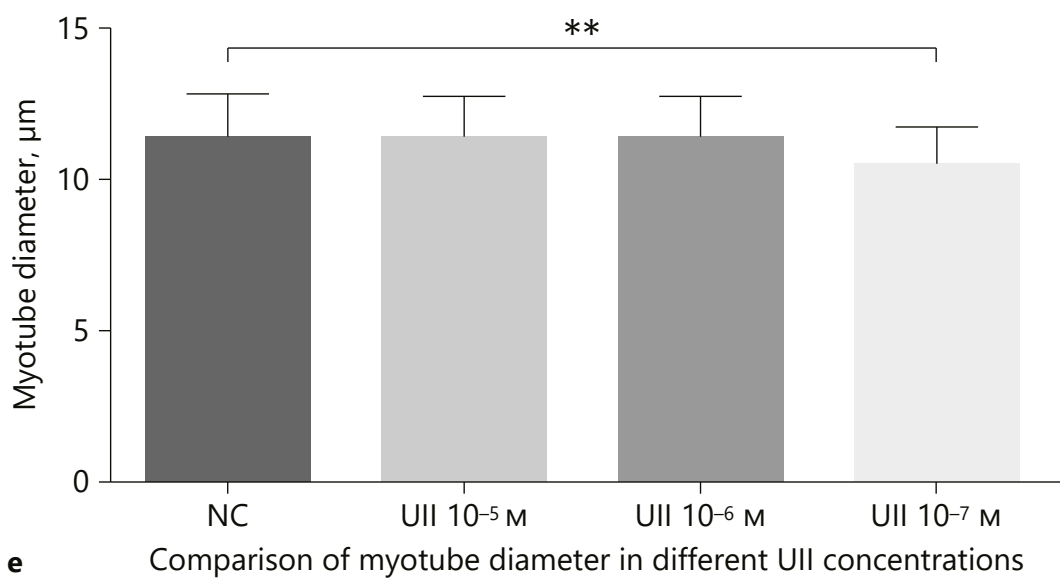

Fig. 6. UII with different exposed concentrations effect on mouse myotube diameters. a NC: PBS serving as a substitution for UII. b-d UII concentration $10^{-5}, 10^{-6}, 10^{-7} \mathrm{M}$ respectively exposed $48 \mathrm{~h}$. e Comparison of myotube diameter in different UII concentration ( ${ }^{* *} p=0.001$ vs. NC). Scale bar $=50 \mu \mathrm{m}$. Exposure time = 48 h. UII, urotensin II; NC, normal control.

marker's upregulation was inhibited. Moreover, in our in vivo study, autophagy activation was accompanied by UII expression upregulation in skeletal muscle tissues in WT CRF mice. When we blocked the UII system action by creating UTKO CRF mice, we found skeletal muscle 

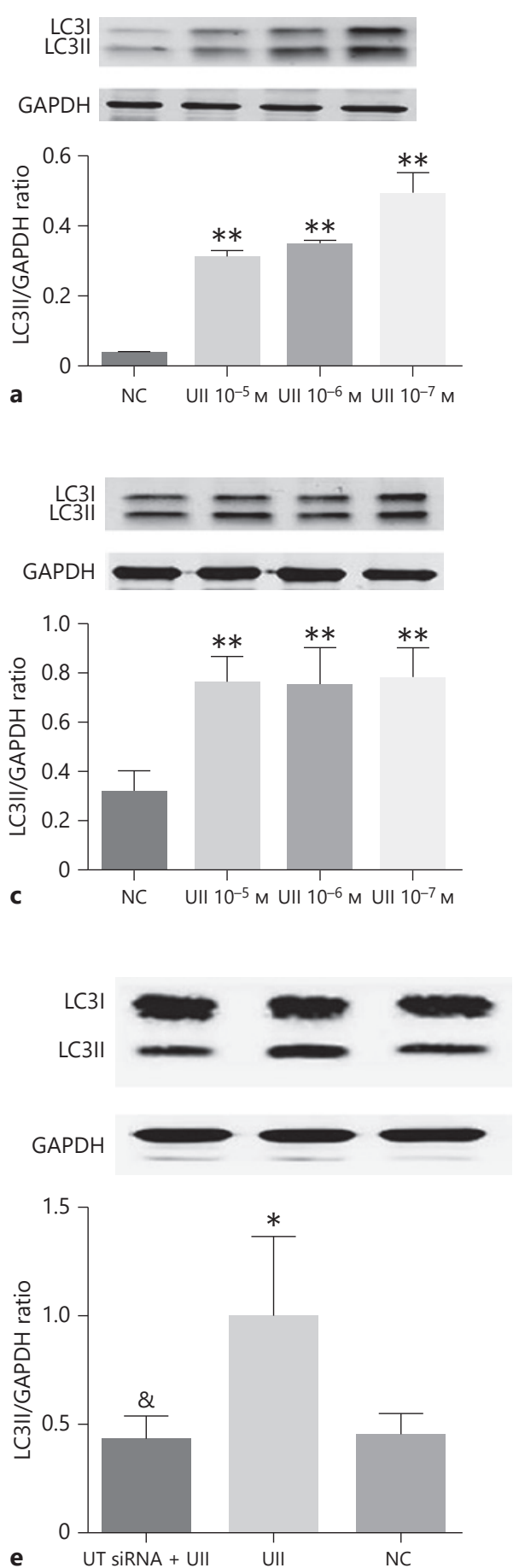
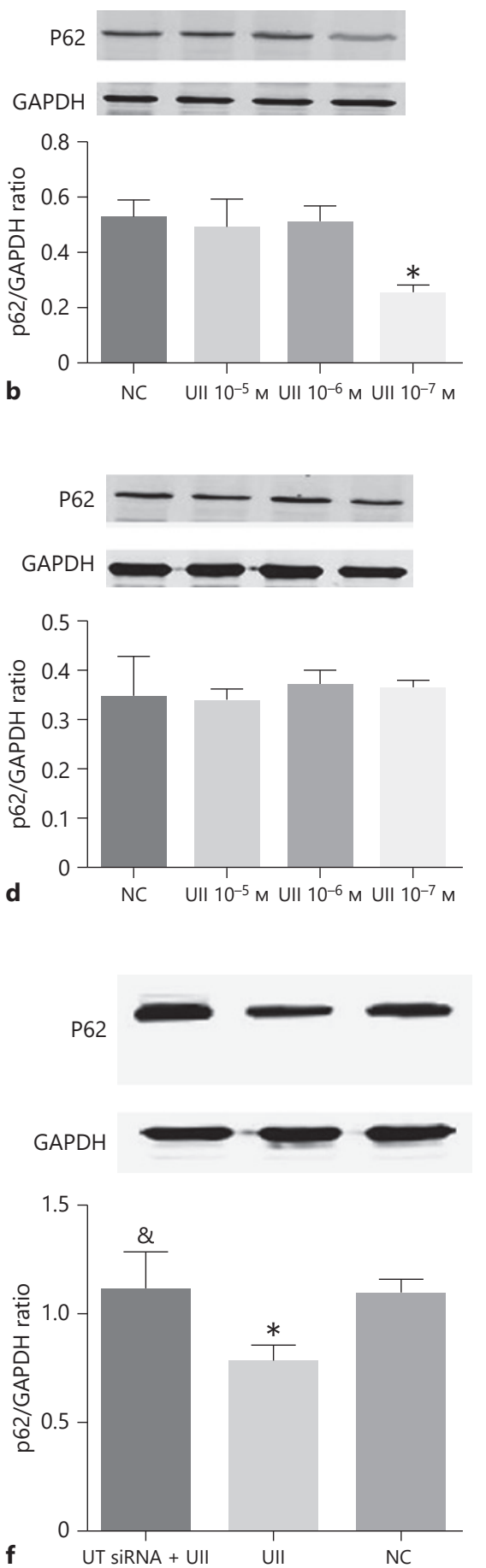

Fig. 7. UII with different UII concentration ( $10^{-5}$ to $\left.10^{-7} \mathrm{M}\right)$, different UII exposed time (6-12 h), and blocking UII receptor action effect on autophagy markers expression in C2C12 cells. a, b Autophagy markers LC3II and p62 expression among UII $10^{-5}$ to $10^{-7} \mathrm{M}$ exposed C2C12 cells for $6 \mathrm{~h}$. c, d UII $10^{-5}$ to $10^{-7} \mathrm{M}$ exposed C2C12 for $12 \mathrm{~h}\left({ }^{*} p<0.05\right.$ vs. NC, ${ }^{* *} p<0.01$ vs. NC). e, f Autophagy markers LC3II and p62 expression among UT siRNA (blocking UII receptor action) combined with UII, UII and NC group $\left({ }^{\&} p<0.05\right.$ vs. UII, ${ }^{*} p<0.05$ vs. NC in e, f). NC: PBS serving as a substitution for UII. UII, urotensin II; NC, normal control. 


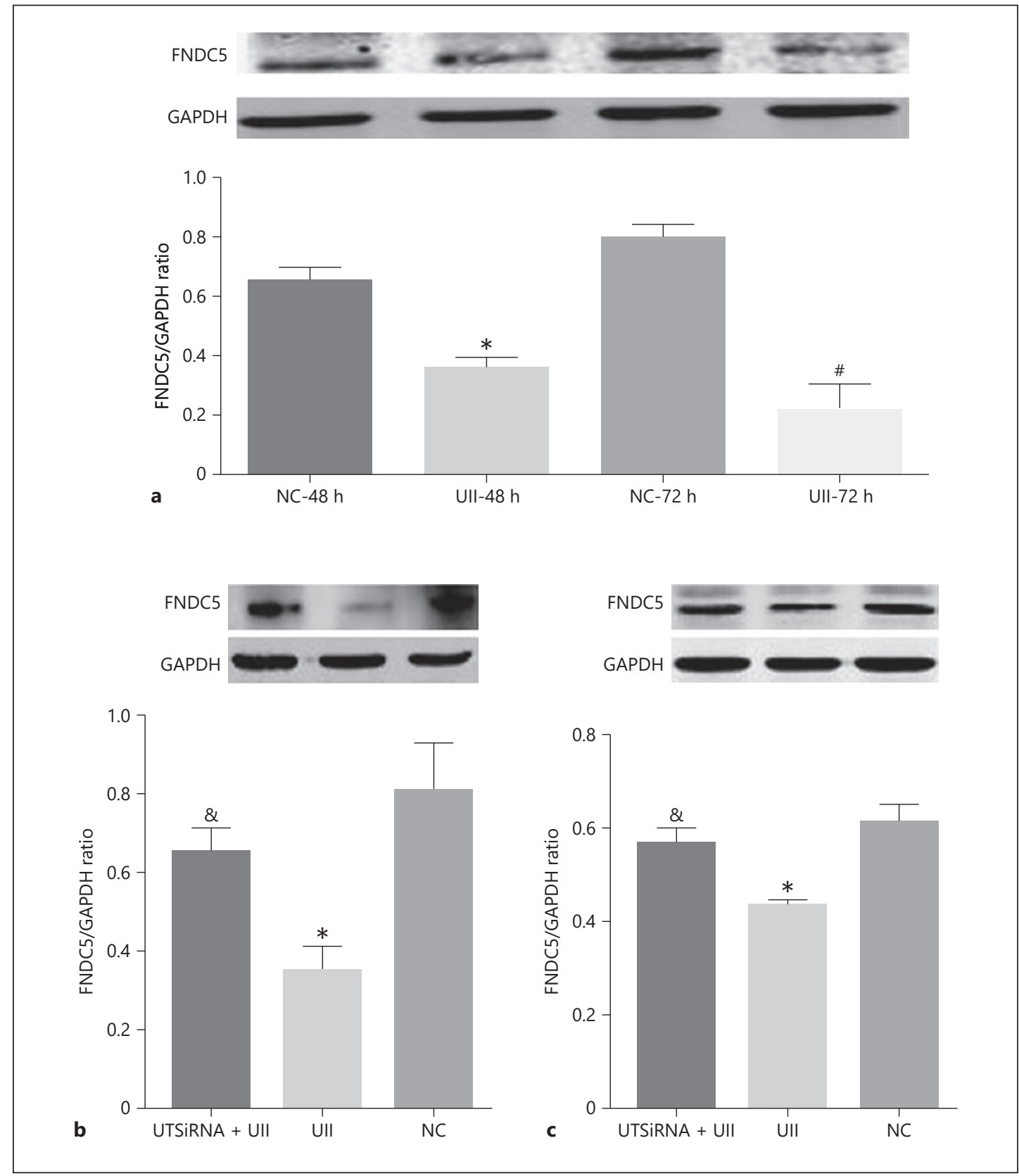

Fig. 8. UII exposure and blocking UII receptor action effect FNDC5 expression in C2C12 cells. a UII exposure group for 48 and $72 \mathrm{~h}\left({ }^{*} p<0.05\right.$ vs. NC-48 h, ${ }^{*} p<0.05$ vs. NC-72 h). b, c FNDC5 expression among blocking UII receptor action (UT siRNA) combined with UII, UII, and NC groups ( ${ }^{\&} p=0.006$ vs. UII exposure alone, ${ }^{*} p=0.001$ vs. NC for $48 \mathrm{~h}$ in $\mathbf{b}$; ${ }^{\&} p=0.004$ vs. UII exposure alone, ${ }^{*} p=0.001$ vs. NC for $72 \mathrm{~h}$ in $\mathbf{c}$ ). NC: PBS serving as a substitution for UII. UII concentration $10^{-7} \mathrm{M}$. UII, urotensin II; NC, normal control; FNDC5, fibronectin type III domain containing 5 .

atrophy was attenuated, and upregulated autophagy was inhibited in chronic renal failure mice.

In our study, we found interesting phenomena that the body weight of UTKO CRF mice was significantly lower than that of the NC and WT CRF mice, but the weight of skeletal muscle was not significantly decreased in comparison to that of the NC group, which was similar to 
Behm et al.'s results [28]. They verified that deletion of the murine prepro-urotensin-II gene is correlated with a lean phenotype and increased cardiac mass.

Previous studies have suggested that elevated $\mathrm{Ca}^{2+}$ concentration occurring in ER stress could induce the development of autophagy [29]. In addition, published studies confirmed that UII can enhance intracellular $\mathrm{Ca}^{2+}$ concentration [30,31], which may explain why UII can directly induce mouse skeletal muscle cells autophagy.

Reza et al. [32] study demonstrated that injection of Irisin in mice induced significant hypertrophy and enhanced grip strength of uninjured muscle. Therefore, diminished Irisin can be one of the reasons for skeletal muscle atrophy.

Our current study is the first to verify that UII can directly inhibit Irisin precursor (FNDC5) expression in mouse skeletal cells through our in vitro study. Moreover, in our in vivo study, we also demonstrated that UII expression upregulation was accompanied by Irisin precursor FNDC5 expression downregulation in WT CRF mice. UTKO can upregulate Irisin precursor (FNDC5) expression in skeletal muscle tissues in chronic renal failure mice.

In conclusion, we are the first to verify UII directly induces mouse skeletal muscle atrophy and autophagy and inhibit FNDC5 (Irisin precursor) expression. UTKO can attenuate skeletal muscle atrophy, inhibit autophagy, and upregulate the FNDC5 expression in chronic renal failure mice.

\section{Statement of Ethics}

The experimental protocols were approved by the Biological Medical Ethics Committee of the Peking University Health Science Center (permit numbers: LA2015154).

\section{Disclosure Statement}

The authors declare no conflicts of interest. The authors alone are responsible for the content and writing of this paper.

\section{Funding Sources}

This study was supported by National Natural Science Foundation (grant nos. 81570663, 81873619, and 81170706) to A.-H.Z.

\section{Author Contributions}

A.-H.Z. and Y.-J.P.: conceptualization. A.-H.Z. and Y.-J.P.: methodology. J.F.: software. Y.-J.P. and S.Z.: validation. Y.-J.P.: formal analysis. Y.-J.P.: investigation. Y.-J.P.: resources. L.-T.A.: data curation. Y.-J.P.: writing, original draft preparation. A.-H.Z. and Y.-J.P.: writing, review and editing. Q.B.: visualization. A.-H.Z.: supervision. A.-H.Z.: project administration. A.-H.Z.: funding acquisition. 


\section{Kidney \\ Blood Pressure \\ Research}

\begin{tabular}{l|l}
\hline Kidney Blood Press Res 2019;44:479-495 \\
\hline DOI: 10.1159/000499880 & $\begin{array}{l}\text { @ 2019 The Author(s). Published by S. Karger AG, Basel } \\
\text { www.karger.com/kbr }\end{array}$ \\
\hline
\end{tabular}

Pan et al.: UII Induces Autophagy and Inhibits FNDC5 Expression in Skeletal Muscle

\section{References}

1 Beddhu S, Wei G, Chen X, Boucher R, Kiani R, Raj D, et al. Associations of dietary protein and energy intakes with Protein-Energy wasting syndrome in hemodialysis patients. Kidney Int Rep. 2017 Apr;2(5):821-30.

2 Kopple JD. Pathophysiology of protein-energy wasting in chronic renal failure. J Nutr. 1999 Jan;129(1S Suppl): 247S-51S.

3 Mitch WE, May RC, Maroni BJ, Druml W. Protein and amino acid metabolism in uremia: influence of metabolic acidosis. Kidney Int Suppl. 1989 Nov;27:S205-7.

4 Guarnieri G, Antonione R, Biolo G. Mechanisms of malnutrition in uremia. J Ren Nutr. 2003 Apr;13(2):153-7.

5 Lee SW, Park GH, Lee SW, Song JH, Hong KC, Kim MJ. Insulin resistance and muscle wasting in non-diabetic end-stage renal disease patients. Nephrol Dial Transplant. 2007 Sep;22(9):2554-62.

6 Zhang YY, Yang M, Bao JF, Gu LJ, Yu HL, Yuan WJ. Phosphate stimulates myotube atrophy through autophagy activation: evidence of hyperphosphatemia contributing to skeletal muscle wasting in chronic kidney disease. BMC Nephrol. 2018 Feb;19(1):45.

7 Fukasawa H, Ishigaki S, Kinoshita-Katahashi N, Niwa H, Yasuda H, Kumagai H, et al. Plasma levels of fibroblast growth factor-23 are associated with muscle mass in haemodialysis patients. Nephrology (Carlton). 2014 Dec; 19(12):784-90.

8 Wang DT, Yang YJ, Huang RH, Zhang ZH, Lin X. Myostatin activates the Ubiquitin-Proteasome and AutophagyLysosome systems contributing to muscle wasting in chronic kidney disease. Oxid Med Cell Longev. 2015; 2015:684965.

9 Bern HA, Lederis K. A reference preparation for the study of active substances in the caudal neurosecretory system of teleosts. J Endocrinol. 1969 Sep;45(1 Suppl):xi-xii.

10 Ames RS, Sarau HM, Chambers JK, Willette RN, Aiyar NV, Romanic AM, et al. Human urotensin-II is a potent vasoconstrictor and agonist for the orphan receptor GPR14. Nature. 1999 Sep;401(6750):282-6.

11 Marchese A, Heiber M, Nguyen T, Heng HH, Saldivia VR, Cheng R, et al. Cloning and chromosomal mapping of three novel genes, GPR9, GPR10, and GPR14, encoding receptors related to interleukin 8, neuropeptide Y, and somatostatin receptors. Genomics. 1995 Sep;29(2):335-44.

12 Vaudry H, Leprince J, Chatenet D, Fournier A, Lambert DG, Le Mével JC, et al. International Union of Basic and Clinical Pharmacology. XCII. Urotensin II, urotensin II-related peptide, and their receptor: from structure to function. Pharmacol Rev. 2015;67(1):214-58.

13 Liu Q, Pong SS, Zeng Z, Zhang Q Howard AD, Williams DL Jr, et al. Identification of urotensin II as the endogenous ligand for the orphan G-protein-coupled receptor GPR14. Biochem Biophys Res Commun. 1999 Dec;266(1):174-8.

14 Huh JY, Dincer F, Mesfum E, Mantzoros CS. Irisin stimulates muscle growth-related genes and regulates adipocyte differentiation and metabolism in humans. Int J Obes. 2014 Dec;38(12):1538-44.

15 Rodney GG, Pal R, Abo-Zahrah R. Redox regulation of autophagy in skeletal muscle. Free Radic Biol Med. 2016 Sep;98:103-12.

16 He WY, Bai Q, A LT, Tang CS, Zhang AH. Irisin levels are associated with urotensin II levels in diabetic patients. J Diabetes Investig. 2015 Sep;6(5):571-6.

17 He WY, Wu F, Pang XX, Chen GJ, A LT, He L, et al. Irisin is associated with urotensin II and protein energy wasting in hemodialysis patients. Kidney Blood Press Res. 2016;41(1):78-85.

18 Pan YJ, He L, Zhou SJ, Zhang LJ, Zhang AH, Zhao YY. Expression of urotensin II is associated with placental autophagy in patients with severe preeclampsia. J Hum Hypertens. 2018 Nov;32(11):759-69.

19 Milan G, Romanello V, Pescatore F, Armani A, Paik JH, Frasson L, et al. Regulation of autophagy and the ubiquitin-proteasome system by the FoxO transcriptional network during muscle atrophy. Nat Commun. 2015 Apr;6(1):6670.

20 Svíglerová J, Kuncová J, Nalos L, Tonar Z, Rajdl D, Stengl M. Cardiovascular parameters in rat model of chronic renal failure induced by subtotal nephrectomy. Physiol Res. 2010;59(Suppl 1):S81-8.

21 Williamson DL, Butler DC, Alway SE. AMPK inhibits myoblast differentiation through a PGC-1 $\alpha$-dependent mechanism. Am J Physiol Endocrinol Metab. 2009 Aug;297(2):E304-14.

22 Zhu M, Liu J, Xiao J, Yang L, Cai M, Shen H, et al. Lnc-mg is a long non-coding RNA that promotes myogenesis. Nat Commun. 2017 Mar;8:14718.

23 Obi Y, Qader H, Kovesdy CP, Kalantar-Zadeh K. Latest consensus and update on protein-energy wasting in chronic kidney disease. Curr Opin Clin Nutr Metab Care. 2015 May;18(3):254-62.

24 Roberts TK, Bailey JL. Beyond nutrition: neuropeptide signaling and muscle mass maintenance in chronic kidney disease. Kidney Int. 2008 Jul;74(2):143-5.

25 Komaba H, Fukagawa M. Secondary hyperparathyroidism and Protein-Energy wasting in End-Stage renal disease. Ther Apher Dial. 2018 Jun;22(3):246-50.

26 Sacheck JM, Hyatt JP, Raffaello A, Jagoe RT, Roy RR, Edgerton VR, et al. Rapid disuse and denervation atrophy involve transcriptional changes similar to those of muscle wasting during systemic diseases. FASEB J. 2007 Jan;21(1):140-55.

27 Mammucari C, Milan G, Romanello V, Masiero E, Rudolf R, Del Piccolo P, et al. FoxO3 controls autophagy in skeletal muscle in vivo. Cell Metab. 2007 Dec;6(6):458-71.

28 Behm DJ, Harrison SM, Duddy G, Hernandez R, Hoffman K, Kuziw J, et al. Targeted deletion of the murine prepro-urotensin-II gene is associated with a lean phenotyp and increased cardiac mass and vascular hyperreactivity. Circulation. 2005;112:U243. 
29 Yorimitsu T, Klionsky DJ. Autophagy: molecular machinery for self-eating. Cell Death Differ. 2005 Nov; 12(Suppl 2):1542-52.

30 Filipeanu CM, Brailoiu E, Le Dun S, Dun NJ. Urotensin-II regulates intracellular calcium in dissociated rat spinal cord neurons. J Neurochem. 2002 Nov;83(4):879-84.

31 Rodríguez-Moyano M, Díaz I, Dionisio N, Zhang X, Avila-Medina J, Calderón-Sánchez E, et al. Urotensin-II promotes vascular smooth muscle cell proliferation through store-operated calcium entry and EGFR transactivation. Cardiovasc Res. 2013 Nov;100(2):297-306.

32 Reza MM, Subramaniyam N, Sim CM, Ge X, Sathiakumar D, McFarlane C, et al. Irisin is a pro-myogenic factor that induces skeletal muscle hypertrophy and rescues denervation-induced atrophy. Nat Commun. 2017 Oct; $8(1): 1104$ 